\title{
Reboxetine Induced Painful Ejaculation: A Case Report
}

\author{
Mehmet Alpay Ates ${ }^{1}$, Onur Durmaz ${ }^{1}$, Yasin Bez²
}

\section{ÖZET:}

Reboksetinle indüklenmiş ag̃rılı ejakülasyon: Bir olgu sunumu

\begin{abstract}
Cinsel ișlev bozuklukları antidepresan ilacların önemli ve sık karșılașılan yan etkilerinden olup bazen tedavinin erken bırakılmasına neden olabilir. Reboksetin önceleri cinsel yan etkisi olmayan bir ilaç olarak bilinmekteydi. Ancak, biz burada reboksetin tedavisine bașladıktan kısa bir süre sonra ag̃rılı ejakülasyon geliștirmiș olan bir olguyu sunmaktayız. Kırk yașındaki bu hastaya depresyonu nedeniyle reboksetin tedavisi bașlanmıştı. Bașlanan $4 \mathrm{mg} / \mathrm{gün}$ dozundaki reboksetin tedavisinden 3 hafta sonra hasta ag̃rılı ejakülasyondan șikayetçi olmaya bașladı. Tedavinin kesilmesinden sonra hastanın ag̃rılı ejakülasyonu kendilig̃inden düzeldi. Reboksetin ile erkek hastaların tedavisinde cinsel yan etkiler, özellikle de ag̃rılı ejakülasyon dahil ejakülasyon bozuklukları akılda bulundurulmalıdır.
\end{abstract}

Anahtar sözcükler: reboksetin, ag̃rilı ejakülasyon, cinsel ișlev bozuklug̃u

Journal of Mood Disorders 2011;1(4):166-8

\section{ABSTRACT: \\ Reboxetine induced painful ejaculation: a case report}

Sexual dysfunction is one of the important and common side effects of the antidepressant drugs. It can sometimes result in early discontinuation of the treatment. Reboxetine was previously not known to cause sexual side effects. However, we present here a case who developed painful ejaculation shortly after initiation of reboxetine treatment. The patient, a 40 years old male, was prescribed reboxetine treatment for his depression. Before the treatment he did not have any sexual dysfunction. Three weeks after inititation of reboxetine $4 \mathrm{mg} /$ day treatment the patient started to complain about painful ejaculation. After cessation of the treatment his painful ejaculation spontaneously subsided. Sexual side effects particularly in terms of ejaculation disorders including painful ejaculation should be kept in mind when treating male patients with reboxetine.

Key words: reboxetine, painful ejaculation, sexua dysfunction

Journal of Mood Disorders 2011;1(4):166-8
${ }^{1}$ Gulhane Military Medical Academy Haydarpasa Training Hospital, Istanbul-Turke ${ }^{2}$ Dicle University School of Medicine Department of Psychiatry, Diyarbakir-Turkey

Yazısma Adresi / Address reprint requests to: Yasin Bez, M.D., Assistant Professor of Psychiatry, Dicle Universitesi Hastanesi, 1. Kat Psikiyatri AD, 21280, Diyarbakir-Turkey

Telefon / Phone: +90-506-474-1838 Faks / Fax: +90-412-248-8523

Elektronik posta adresi / E-mail address: yasinbez@gmail.com

Kabul tarihi / Date of acceptance: 18 Aralık 2011 / December 18, 2011

Bag̃ıntı beyanı: M.A.A., O.D., Y.B.: Yazarlar bu makale ile ilgili olarak herhangi bir çıkar çatıșması bildirmemișlerdir.

Declaration of interest: M.A.A., O.D., Y.B.: The authors reported no conflict of interest related to this article.

\section{INTRODUCTION}

Antidepressant-induced sexual dysfunction sometimes may be an important reason for noncompliance with the medication $(1,2)$. Sexual dysfunction associated with antidepressant use interferes with quality of life, self-esteem, mood, and relationship with partner $(1,3)$. Sexual side-effects of the antidepressants are important aspects of these drugs to be considered when planning a treatment regimen. Decreased sexual arousal and libido, orgasm, and ejeculation problems are among themost common sexual side effects of the antidepressants (4). According to some studies in the literature, types of the sexual dysfunction varies across antidepressant classes. Tricyclic antidepressants (TCAs) may have negative impact on all phases of sexual behavior (5), whereas selective serotonin reuptake inhibitors (SSRIs) are mainly associated with ejaculation and orgasm problems such as delay or inhibition of them (6). Additionally, selective noradrenalin reuptake inhibitors (sNARIs) occasionally cause erectile dysfunction (7).

Sexual side effects resulting from antidepressants may be mediated by a number of central and peripheral mechanisms. Serotonergic system plays a major role in etiology of sexual dysfunction during antidepressant treatment. Regarding to sexual side effect profile, TCAs provoke higher rates of sexual dysfunction than SSRIs and SNRIs, respectively. Bupropione, moclobemide, reboxetine, mirtazapine, nefazodone have more favorable sexual side effect profile compared to escitalopram, paroxetine, venlafaxine, sertraline, or fluoxetine $(1,8)$. Several strategies have been employed for management of patients with sexual dysfunction associated with antidepressant treatment, including spontaneous resolve, 
behavioral strategies to modify sexual technique, individual and couple psychotherapy, delaying the intake of antidepressants until after sexual activity, reduction in daily dosage, use of adjuvant treatments, and switching to a different antidepressant (9).

Reboxetine which mainly acts by binding to the norepinephrine transporter and blocking the reuptake of extracellular norepinephrine, is the first selective norepinephrine reuptake inhibitor used in depression treatment. It has been reported that reboxetine has no predominant sexual side effects $(2,4)$. Here, we describe a patient with major depressive disorder, who experienced sexual dysfunction (i.e. painful ejaculation) associated with reboxetine treatment.

\section{CASE}

A 40 year old man was referred to our outpatient clinic with depressive symptoms. He had been suffering from anergia, anhedonia, avolition, depressed mood, and pessimistic thoughts known as characteristic symptoms of depression without any sexual dysfunction. His Montgomery Asperg Depression Rating Scale (MADRS) score was 39 in his first visit. He was sexually active and reported 1 or 2 episodes of sexual intercourse per week. He was diagnosed with "Major Depressive Disorder" according to Diagnostic and Statical Manual of Mental Disorders, 4th edition (DSM-IV). He reported neither previous psychiatric history nor use of any antidepressant drug. Reboxetine $4 \mathrm{mg} /$ day was prescribed to the patient for his depression considering his predominant symptoms related with psychomotor retardation. After 3 weeks, during the second visit, he reported painful ejaculation that began concurrent with initiation of the treatment. Reboxetine treatment was stopped after his complaint of painful ejaculation. After cessation of reboxetine his ejaculatory complaints subsided spontaneously without any need for further medical interventions. After discussing alternative treatments with the patient, cognitive behavioral psychotherapy was planned for his depression. During the following 8 weeks the patient was provided psychotherapy as planned. At the end of the last session, his MADRS score was 14 (>\%50 reduction), which indicates significant clinical improvement. He reported neither ejaculation problem nor any other sexual dysfunction during this treatment period.

\section{DISCUSSION}

It is widely accepted that antidepressant reboxetine has a considerably favorable sexual side effect profile. Its nonserotonergic mechanism makes it superior to other antidepressant agents. Reboxetine can be an alternative drug when sexual side effects are observed with the other antidepressant agents. Supporting this suggestion some previous studies reported that sexual function and satisfaction in depressed patients had improved greater during treatment with reboxetine than treatment with paroxetine or fluoxetine $(2,10)$. However, it should be kept in mind that reboxetine is not totally free of sexual side effects. Reboxetine-induced prolonged orgasm of reduced intensity and seminal emission after defecation was reported by Haberfellner in 2002 (11). Both disorders were accompanied by pain and ceased within two days after discontinuation of the drug. The side effects of reboxetine may include painful ejaculation as emerged in this case. Painful ejaculation following the administration of reboxetine has been previously described in two patients by Demyttenaere and Huygens in 2002 (7). It has also been shown that tamsulosin, the selective alpha1A-adrenoceptor antagonist, rapidly and completely resolved the painful ejaculation and urinary hesitancy in these patients. Abnormal ejaculation (primarily painful ejaculation) was also reported as a side effect by $20 \%$ $(11 / 56)$ of male patients receiving reboxetine by Clayton et al in 2003 (2). In addition to other ejaculation side effects, our case also provides modest evidence that painful ejaculation can also occur with reboxetine treatment. The mechanism of antidepressant induced painful ejaculation remains obscure. To explain it two possible mechanisms were proposed. First is the partial blockade of peripheral sympathetic adrenergic receptors similar to the one observed during TCA use. It is suggested that this action could interfere with coordinated contractions of the smooth muscles involved in semen transport and thus inducepainfulspasms (12). Secondis that thenoradrenaline potentiation could interfere with the ejaculatory mechanism, thereby inducing a painful spasticity. This hypothesis can indeed explain why painful ejaculation has predominantly been described both with TCAs (desipramine, imipramine, nortriptyline and clomipramine) and reboxetine. It could also explain why painful ejaculation has been reported with the dual uptake inhibitor venlafaxine (13). 


\section{CONCLUSION}

Sexual dysfunctions are common problems encountered during antidepressant treatment and should be assessed thoroughly during treatment, as well as during the course of psychiatric disorders. The data available about reboxetine suggest that sexual side effects with this drug are infrequent. Although reboxetine may be a good alternative for patients suffering from sexual side effects of other antidepressants, individual

\section{References:}

1. Kinzl JF. Major depressive disorder, antidepressants and sexual dysfunction. Neuropsychiatr 2009;23:134-138.

2. Clayton AH, Zajecka J, Ferguson JM, Filipiak-Reisner JK, Brown MT, Schwartz GE. Lack of sexual dysfunction with the selective noradrenaline reuptake inhibitor reboxetine during treatment for major depressive disorder. Int Clin Psychopharmacol 2003;18:151156.

3. Williams VS, Edin HM, Hogue SL, Fehnel SE, Baldwin DS Prevalence and impact of antidepressant-associated sexual dysfunction in three European countries: replication in a crosssectional patient survey. J Psychopharmacol 2010;24:489-496.

4. Labbate LA, Croft HA, Oleshansky MA. Antidepressant-related erectile dysfunction: management via avoidance, switching antidepressants, antidotes, and adaptation. J Clin Psychiatry 2003;64:11-19.

5. Harvey KV, Balon R. Clinical implications of antidepressant drug effects on sexual function. Ann Clin Psychiatry 1995;7:189-201.

6. Rosen RC, Lane RM, Menza M. Effects of SSRIs on sexual function: a critical review. J Clin Psychopharmacol 1999;19:67-85. vulnerabilities for such side effects should be considered. Sexual side effects particularly in terms of ejaculation disorders that include painful ejaculation should be taken into account prior to administration of reboxetine or while switching to reboxetine due to sexual side effects induced by other antidepressant agents. Clinicians should also consider to discuss alternative treatment strategies like psychotherapy with these patients who are vulnerable to some side effects of antidepressants including ejaculatory problems.

7. Demyttenaere K, Huygens R. Painful ejaculation and urinary hesitancy in association with antidepressant therapy: relief with tamsulosin. Eur Neuropsychopharmacol 2002;12:337-341.

8. Baldwin DS. Sexual dysfunction associated with antidepressant drugs. Expert Opin Drug Saf 2004;3:457-470.

9. Higgins A, Nash M, Lynch AM. Antidepressant-associated sexual dysfunction: Impact, effects, and treatment. Drug Health Patient Saf. 2010;2:141-50.

10. Baldwin DS, Bridgman K, Buis C. Resolution of sexual dysfunction during double-blind treatment of major depression with reboxetine or paroxetine. J Psychopharmacol 2006;20:91-96.

11. Haberfellner EM. Sexual dysfunction caused by reboxetine Pharmacopsychiatry 2002;35:77-78.

12. Petrie WM. Sexual effects of antidepressant and psychomotor stimulant drugs. Mod Probl Pharmacopsychiatry 1980;15:77-90.

13. Michael A. Venlafaxine induced painful ejaculation. Br J Psychiatry 2000;177:282-283. 